\title{
EdITORIAL
}

\section{Ten years old and still learning to walk}

\author{
Jim Ducharme, MD
}

VERSION FRANÇAISE À LA PAgE 129

$\mathrm{I}_{\mathrm{i}}^{\mathrm{t}}$ was April 1999 when a new journal was born, coming to life crying and wailing as do all healthy babies. Its parents couldn't initially decide on a name but finally agreed that the Canadian Journal of Emergency Medicine (CJEM) was best. Those parents were so proud, as evidenced by their first proclamations: "The first thing you notice when you become the editor of a new journal is that you have no articles to publish. This is good. It allows you to determine, without undue influence, the direction the journal should take."1

CJEM's first senior associate editor, Garth Dickinson, noted, "Another emergency medicine journal? There are scads already! Some arrive even if you don't subscribe. CAEP has already tried this. Remember the CAEP Review from the early '80s? It wasn't just the lousy name.'2 Ah parents, they are so proud they just can't contain their enthusiasm!

And so it began. How did we ever get off the ground when most viewers were betting the odds against our survival? After all, we had failed before, as Garth Dickinson wrote so concisely. The answer is as simple as it is incredulous: pure willpower. Grant Innes, as the first editor-inchief, willed CJEM into existence, spending untold hours each week in his head office - the basement of his house - working feverishly into the middle of the night with an equally committed managing editor - his wife.

The second reason we succeeded: no pride. Have you any idea how much time was spent begging (and threatening) for articles of any kind for an unknown, nonindexed journal to come to life every 2 months?

The third reason: belief in the quality of academic emergency medicine in this country, complemented by absolute ignorance about how much volunteer work would be required. Grant brought together our first associate editors (Ian G. Stiell, Jacques S. Lee, Jim Thompson, Laurie J. Morrison, Julie Spence, John Ross, Michael J. Bullard, David J. Rhine, Anthony S. Taylor, Cheri Nijssen-Jordan, Bruce Minnes, Al Huber, Tim Allen, Isser Dubinsky, Jason R. Frank, Kirk Hollohan and Jeffrey L. Arnold) and with their energy and knowledge enabled "sows' ears to become silk purses." We are all very grateful for their time, commitment and energy.

As we grew, we became the source of internationally recognized standards in emergency medicine such as the Canadian Emergency Department Information System ${ }^{3}$ and the Canadian Emergency Department Triage and Acuity Scale. ${ }^{4}$ We published ground-breaking information on SARS at a time when it was captivating the world, ${ }^{5}$ all while still not indexed by the US National Library of Medicine as an officially recognized academic journal.

The efforts to grow have been painful and arduous, yet all worthwhile. Volunteer effort is still huge, and largely unrecognized. Trying to minimize the load for each reviewer or editor is difficult, given the limited number of Canadian academic physicians available — yet so many do give their time. How, as CJEM's second editor-in-chief, can I ever thank them enough? Perhaps the best thanks might be relaying the positive comments we receive on a regular basis about the quality of the journal and how so many people identify CJEM as being a relevant Canadian medical journal. Perhaps another is by being witness to the ever-increasing number of submissions we receive from abroad, and the ever-increasing quality of those submissions. It was not that many years ago when Grant, Garth and I would spend hours rewriting articles to ensure we had enough acceptable articles for publication. Today we

Editor-in-Chief, CJEM; Clinical Professor of Medicine, McMaster University, Hamilton, Ont.

All editorial matter represents the views of the authors and not necessarily those of CJEM or the Canadian Association of Emergency Physicians.

CJEM 2009;11(2):127-8 
have the luxury of asking authors to do better, all the while reviewing quality submissions.

"Are we there yet?" is a popular catchphrase, and the answer is, "No, we are not." I am not sure we ever will be. Heck, I am not even sure I know where "there" is. We are indexed, as joyfully announced by Grant Innes in $2007 .{ }^{6}$ We are publishing politically important position papers ${ }^{7}$ and state-of-the-art clinical guidelines. ${ }^{8}$ We clearly do not have the impact factor of Lancet, Science, or, for that matter, Academic Emergency Medicine. But you know what? I really do not care if we ever attain such lofty objective successes. My only hopes are that we continue to impact the Canadian emergency physician with every issue, and that we succeed in making every issue "fun" and interesting for our readers. Isn't that what any 10 -year-old would be proud to have accomplished?

So I am going to go back and "kick the can" to see what happens. Who knows, maybe someday Kirby can beat Marth at Super Smash Bros. Brawl. Maybe the geek will get invited to the dance. But at age 10, CJEM's best years are ahead of it. Golly, isn't that what life is all about when you are 10: nothing is impossible and everything is in front of you?

\section{Competing interests: None decared.}

Keywords: emergency medicine, publication, guidelines, position statement

\section{References}

1. Innes G. Ruminations on a new journal [editorial]. CJEM 1999; $1: 14-6$.

2. Dickinson G. A new EM journal? [editorial] CJEM 1999;1:17-9.

3. Grafstein E, Unger B, Bullard M, et al; Canadian Emergency Department Information System (CEDIS) Working Group. Canadian Emergency Department Information System (CEDIS) Presenting Complaint List (Version 1.0). CJEM 2003;5:27-34.

4. Beveridge R, Clark B, Janes L, et al. Canadian Emergency Department Triage and Acuity Scale: implementation guidelines. CJEM 1999;1(suppl):S2-28.

5. Wong WN, Sec ACH, Lau RFL, et al. Accuracy of clinical diagnosis versus the World Health Organization case definition of the Amoy Garden SARS cohort. CJEM 2003;5:384-91.

6. Innes G. Ruminations of a (newly indexed) journal. CJEM 2007;9:5-8.

7. Snider CE, Ovens H, Drummond A, et al. CAEP statement on gun control. CJEM 2009;11:64-72.

8. Green RS, Djogovic D, Gray S, et al. Canadian Association of Emergency Physicians Sepsis Guidelines: the optimal management of severe sepsis in Canadian emergency departments. CJEM 2008;10:443-59.

Correspondence to: cjem@caep.ca 